\title{
Hydatidosis, cysticercosis, and tuberculosis rates in bovine slaughtered under state sanitary inspection in Rio Grande do Sul, Brazil
}

\section{Roque Fernando Pinheiro Bica ${ }^{1}$ Marina Venturini Copetti ${ }^{1,2}$ Mário Celso Sperotto Brum ${ }^{1 *}$}

${ }^{1}$ Programa de Pós-Graduação em Ciência Animal, Universidade Federal do Pampa (Unipampa), 97.508-000, Uruguaiana, RS, Brasil. E-mail:mariobrum@unipampa.edu.br. "Corresponding author.

${ }^{2}$ Departamento de Tecnologia e Ciência de Alimentos, Centro de Ciências Rurais, Universidade Federal de Santa Maria, Santa Maria, RS, Brasil.

ABSTRACT: This study sought to evaluate the occurrence of lesions suggestive of hydatidosis, cysticercosis, and tuberculosis in animals slaughtered under sanitary inspection of the Divisão de Inspeção de Produtos de Origem Animal (DIPOA), in the state of Rio Grande do Sul. Condemnation data between the years 2009 and 2017 were obtained from Secretaria da Agricultura Pecuária e Irrigação (SEAPI) and presented according to the administrative regions established by SEAPI. In that period, 7,509,544 cattle were slaughtered and condemnations occurred in all regions of the state at varying levels. The mean condemnation values showed the presence of hydatidosis in 523,399 (6.97\%), cysticercosis in 92,277 (1.23\%), and tuberculosis in 10,595 (0.14\%) cattle carcasses. The mean values of hydatidosis diagnoses were higher in the regions of Alegrete (14.19\%), Bagé (19.62\%), and Pelotas (17.71\%). The regions of Osório (1.86\%), Santa Maria (2.10\%), and São Luiz Gonzaga $(1.83 \%)$ had highest rates of cysticercosis condemnations. All regions maintained an average bovine tuberculosis diagnosis rate of less than $1 \%$ and Estrela region had the highest index (0.70\%). Results showed that the three diseases occurred in all regions of the state, the average prevalence rates in each region are variable, and distribution seems to be regionalized. This knowledge contributes to the plans for controlling these diseases, which are zoonoses that cause economic losses to the productive sector.

Key words: meat inspection, cysticercosis, hydatidosis, zoonosis.

Ocorrência de hidatidose, cisticercose e tuberculose em bovinos abatidos sob inspeção estadual no Rio Grande do Sul, Brasil

RESUMO: O objetivo do estudo foi avaliar a ocorrência de lesões sugestivas de hidatidose, cisticercose e tuberculose em carcaças bovinas oriundas de abatedouros frigoríficos sob inspeção sanitária da Divisão de Inspeção de Produtos de Origem Animal (DIPOA), no Estado do Rio Grande do Sul. Os dados de condenações entre os anos de 2009 e 2016 foram obtidos junto a Secretaria da Agricultura Pecuária e Irrigação (SEAPI) e apresentados conforme as regiões administrativas estabelecidas pela SEAPI. Nesse período foram abatidos 7.509 .544 bovinos e as condenações estiveram presentes em todas as regiões do estado, em niveis variáveis. Os valores médios das condenações demonstraram a presença de hidatidose em 523.399 (6,97\%), cisticercose em 92.277 (1,23\%) e tuberculose em 10.595 (0,14\%) das carcaças bovinas. Os valores médios de condenações por hidatidose foram maiores nas regionais de Alegrete (14,19\%), Bagé (19,62\%) e Pelotas (17,71\%). As regionais de Osório (1,86\%), Santa Maria (2,10\%) e São Luiz Gonzaga (1,83\%) apresentaram as maiores médias para a presença de cisticercose. Todas as regiões mantiveram uma média abaixo de $1 \%$ para condenaçães por tuberculose bovina e a região de Estrela obteve o maior indice $(0,70 \%)$. Os resultados demonstram que as três enfermidades são causas de condenações em todas as regiões do estado, os indices médios de prevalência em cada região são variáveis e a distribuição parece ser regionalizada. Esse conhecimento poderá subsidiar a elaboração de planos de controle dessas enfermidades, as quais, além do aspecto zoonótico, são responsáveis por perdas econômicas ao setor produtivo pelas condenações de carcaças e órgãos dos bovinos.

Palavra-chave: inspeção sanitária, cisticercose, hidatidose, tuberculose, zoonose.

\section{INTRODUCTION}

Bovine farming is one of the most important sectors of Brazilian agribusiness. In 2016 the country possessed the second largest effective herd in the world (218.2 million head). In Southern Brazil, official data indicate that the cattle herd in Rio Grande do Sul consists of approximately 13.6 million animals distributed across 496 municipalities (IBGE, 2017).
In Brazil, slaughtered animals are subject to ante-mortem and post-mortem inspection procedures, which follow hygienic-sanitary and technological guidelines provided in the Regulation of the Industrial and Sanitary Inspection of Products of Animal Origin (RIISPOA) (BRAZIL, 2017). The administrative organization of the official sanitary inspection service in Brazilian slaughterhouses is regulated by Federal Law No. 7.889 instituted in 1989, which makes the Ministry 
of Agriculture, Livestock, and Food Supply (MAPA) responsible for regulation and inspection of establishments engaged in interstate or international commerce. The State Secretariats of Agriculture, Federal Districts, and Territories should regulate the establishments carrying out inter-municipal trade. Moreover, products of animal origin subject to municipal sanitation shall only be marketed locally (BRASIL, 1989).

Biological agents in meat products result in direct and indirect losses to affected animals, especially those with zoonotic potential that constitute a hazard to public health (FAO, 1986). Preventively, during post-mortem inspection, carcass, carcass parts, cavities, organs, tissues, and lymph nodes are examined by palpation, examination, and incision to find lesions compatible with infectiouscontagious diseases (BRASIL, 2017). Among the most frequently observed infectious lesions in Brazil are those associated with hydatidosis, cysticercosis, and tuberculosis (SANTOS et al., 2010).

Hydatidosis is a disease caused by the larval form of the Echinococcus granulosus parasite in the small intestine of dogs and other carnivores (GERMANO \& GERMANO, 2008; OIE, 2014). The larval form (hydatid or hydatid cyst), occurs in cattle, sheep, pigs, equines, and humans. Man, as an accidental host, has infection sites in the liver, lungs, kidneys, heart, cranial cavity, and bones. Both human and bovine infection occurs by environmental ingestion of E. granulosus eggs from water or food contaminated by canine feces (OIE, 2014). Echinococcosis mainly affects areas with restricted access to health services, particularly in populations that slaughter and consume animals without inspection and feed domestic animals raw viscera. These habits facilitate the parasite life cycle (FAO, 1986; IRABEDRA, 2010).

Bovine cysticercosis is caused by the metacestoid phase of the intestinal cestode Taenia saginata, which establishes humans as the definitive and cattle as the intermediate hosts. The lesions are cystic, measuring approximately $10 \mathrm{~mm}$ when mature, and are present mainly in the heart, tongue, masseter muscle, and diaphragm of bovines (OIE, 2014). Humans can become infected by ingesting raw or undercooked meat and / or viscera that have not been properly inspected (OIE, 2014).

Bovine tuberculosis is a chronic infectious and contagious disease that is mainly caused by Mycobacterium bovis and usually affects cattle and buffalo (OIE, 2014). Many infected animals do not show clinical signs, and disease is confirmed by the tuberculin test or postmortem findings (MURAKAMI et al., 2009). This infection could be involved in the etiology of human tuberculosis (SHAKESPEARE,
2009). Transmission usually occurs by ingestion of unpasteurized milk or milk products, primarily affecting children, elderly, and immunocompromised hosts (O'REILLY, DABORN, 1995; SHAKESPEARE, 2009). Incidence of pulmonary tuberculosis caused by $M$. bovis is higher in rural workers and immunosuppressed individuals when compared to the general population (OIE, 2014).

The objectives of the sanitary inspection system are to guarantee food safety, since it aims to prevent the marketing of animal protein from infected and / or disease animals, as well as, prevent the consumption of viscera and other animal by-products (BRASIL, 2010). This research aimed to retrospectively evaluate the occurrence of lesions suggestive of cysticercosis, hydatidosis, and tuberculosis in bovine carcasses from slaughterhouses under state inspection in the state of Rio Grande do Sul between 2009 and 2017.

\section{MATERIALS AND METHODS}

Slaughtering data and hydatidosis, cysticercosis, and tuberculosis infection rates between 2009 and 2017, from slaughterhouses in Rio Grande do Sul (RS) subject to the State Sanitary Inspection system, were obtained from the Division of Inspection of Products of Animal Origin (DIPOA). Criteria for identification and infection of carcasses followed the regulations set by the Inspection Service for Animal Products of Rio Grande do Sul Law No. 10,691, which was based on the Regulation of Industrial and Sanitary Inspection of Products of Animal Origin (RIISPOA) (BRASIL, 1952) revoked in 2017 by Decree No. 9,013 (BRASIL, 2017).

Information on infection rates at the time of slaughtering is recorded by official veterinarians on standard DIPOA forms. Data is registered according to the municipality of origin of the slaughtered animal and compiled in 19 administrative regions defined by the Secretariat of Agriculture, Livestock, and Irrigation (SEAPI) of Rio Grande do Sul (Figure 1). The data collected from these regions, encompassing 496 municipalities, are sent to the State Statistical Office. The data were tabulated in Microsoft Excel worksheets (Microsof Office ${ }^{\circledR}$ ) and analyzed in a descriptive way in this retrospective study.

\section{RESULTS AND DISCUSSION}

Between 2009 and 2017, a total of 7,509,544 cattle were slaughtered, under the supervision of DIPOA, in the state of Rio Grande do Sul. The distribution of the origin of slaughtered animals, and 
occurrence of lesions compatible with hydatidosis, cysticercosis, and tuberculosis, are shown in Table 1.

Identification of lesions on carcasses can indicate the presence of infections in the herd. These diseases reduce animal productivity (weight gain, discard rate, and reproductive age), also reducing the profitability of the meat industry (BRASIL, 2017; FRUET et al., 2013). In the present study, loss calculations were not performed, but losses due to the commercialization of the affected organs or specific treatment of the carcasses could be considered.

Number of animals slaughtered and registered decreased in the years 2009 and 2013, which was likely due to the implantation of computerized systems generating difficulties with data storage during the transition. Despite the variations in the number of animals registered in the system, the infection rates were similar.

Although, the regions of Alegrete, Bagé, and Uruguaiana account for approximately $70 \%$ of the Rio Grande do Sul state cattle herd (IBGE, 2017), they represented only $6.8 \%, 5.4 \%$, and $5 \%$ of cattle slaughtered under state inspection during the period (Figure 1). This disparity may be the result of targeted cattle movement to slaughterhouses with federal inspection, which enable interstate or international commercialization that confer economic advantages to producers Conversely, the largest number of cattle slaughtered under state inspection originated from the regions of Porto Alegre (16.6\%) and Pelotas $(13.8 \%)$. These two regions are characterized by high population density and consequent high demand for meat. Also, in the Pelotas region, 11 abattoirs are under DIPOA inspection. Among the 11 inspected abattoirs is the plant responsible for the largest volume of cattle slaughtered annually in Rio Grande do Sul (SANTOS et al., 2010).

The infection rate for the three diseases had little variation over the nine years evaluated (Table 1), demonstrating the presence and maintenance of the pathogens in the cattle herd of Rio Grande do Sul. Mean infection rates are presented according to the origin of the animals, regionally (Figure 2). One can observe the presence of the three infectious agents in all regions but occur at varying levels between them. Hydatidosis was detected at higher levels in cattle from Alegrete, Bagé, and Pelotas regions. Cysticercosis was observed more frequently in animals from the Santa Maria, Osório, and

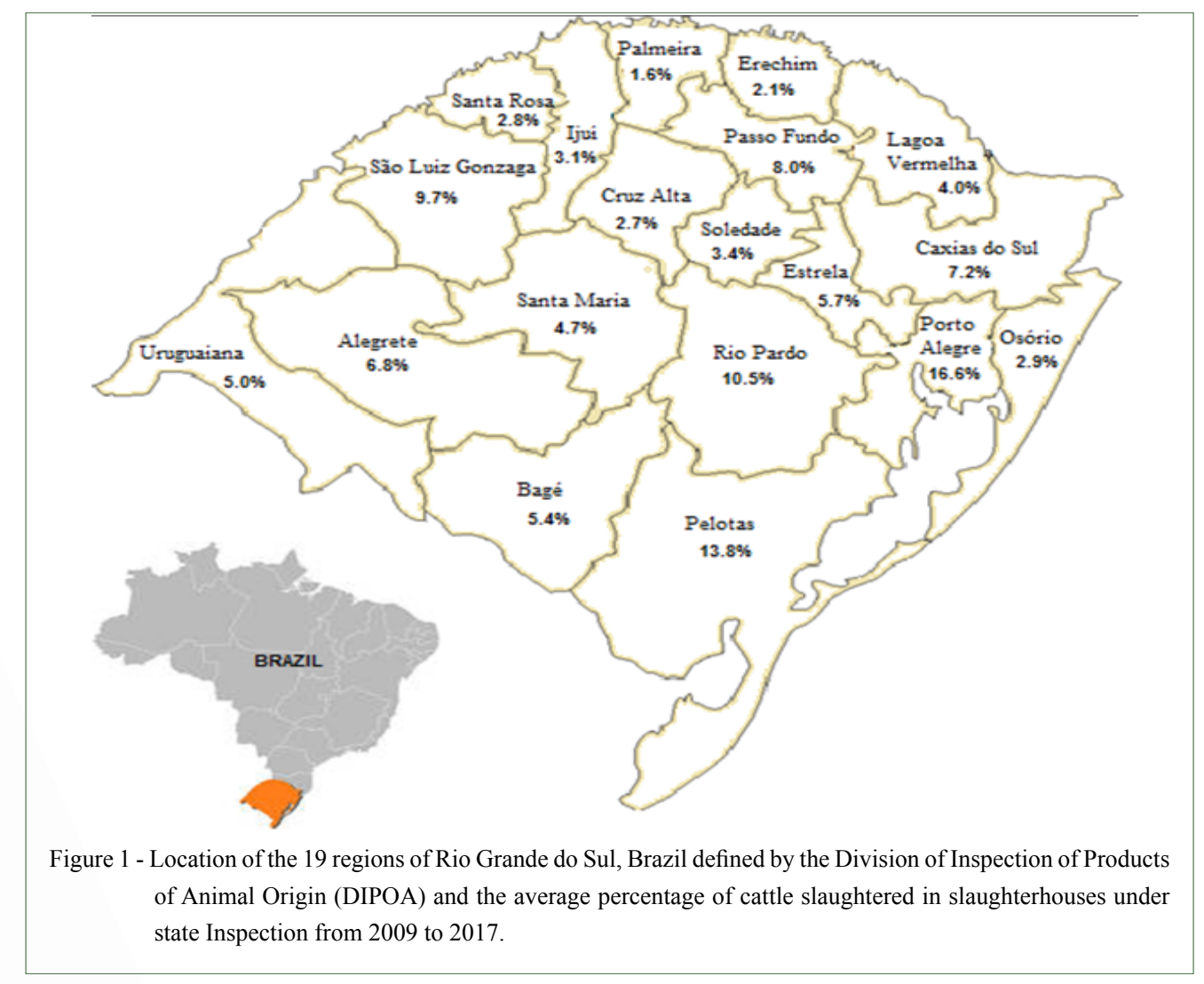

Ciência Rural, v.48, n.8, 2018. 


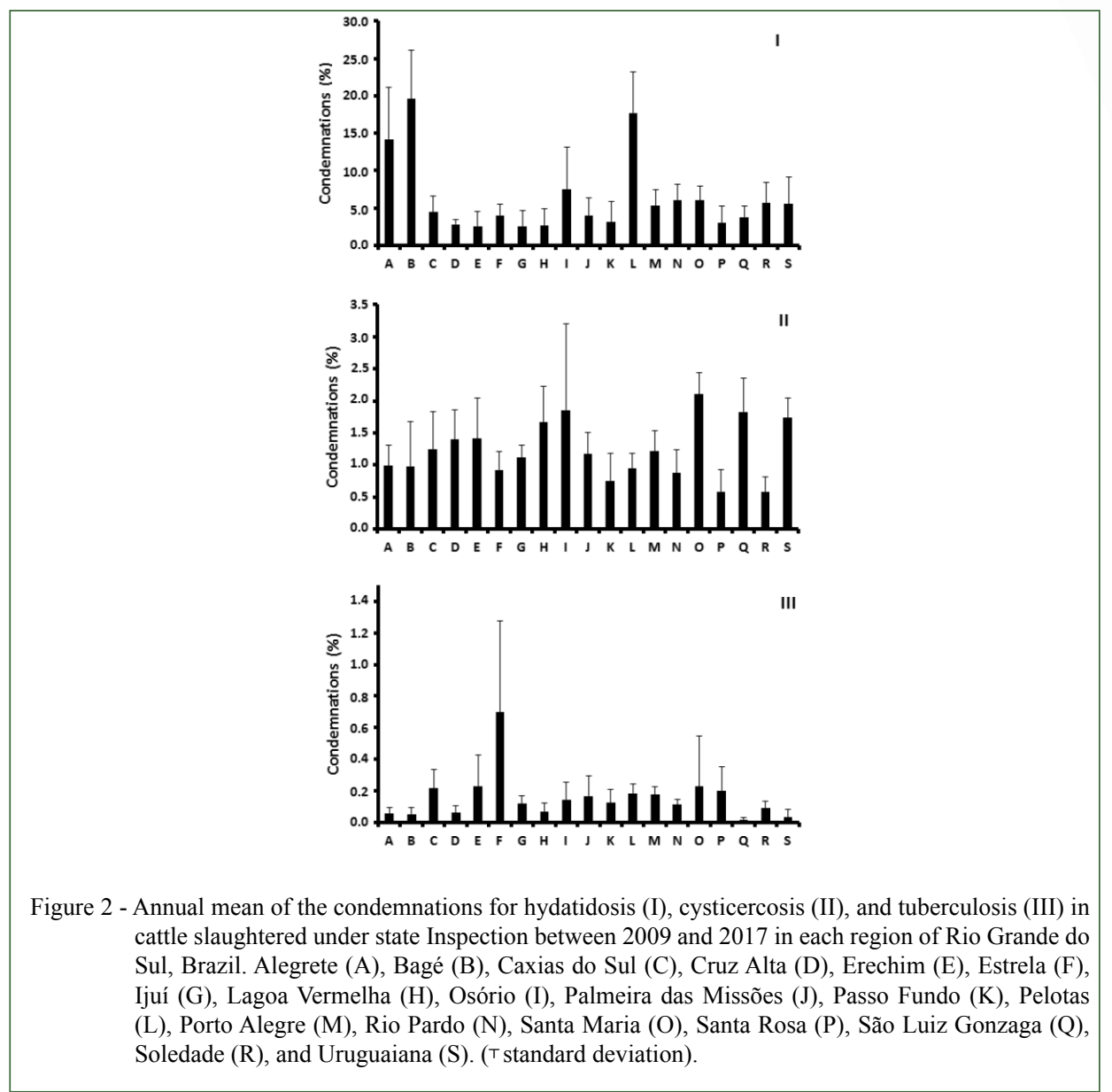

São Luiz Gonzaga regions, and tuberculosis was present mainly in animals from Estrela region.

In the present study, lesions typical of hydatidosis $(6.97 \%)$ represented the highest infection rate (Table 1). However, $51.5 \%$ of hydatidosis infections were related to cattle from the municipalities in the Southern half of Rio Grande do Sul (regions of Alegrete, Bagé, Pelotas and Uruguaiana). These regions are characterized by extensive bovine and sheep production, associated with the presence of dogs on these properties. This scenario is associated with the cultural habit of breeders to slaughter sheep on their property, allowing dogs to access raw viscera (HERNÁNDEZ-RUSSO \& CABRERA-STÁBILE, 2010) and further perpetuation of thydatidosis / echinococcosis cycle. The maintenance of this cycle is perpetuated by the resistance of $\mathrm{dog}$ owners to performing continuous prophylactic treatment to interrupt the parasite cycle (FARIAS et al., 2004).

In the Uruguaiana region, the mean condemnation rate for hydatidosis over the evaluated years was $5.55 \%$. However, the indices varied considerably. In $2009,10 \%$ of infections were associated with this disease, followed by a steady and gradual reduction to $0.15 \%$ in 2012 . Unfortunately, infection rates returned to about $7 \%$ in subsequent years. This wide variation occurred because the municipalities of Santana do Livramento and Quaraí, belonging to this regional and with expansive bovine and ovine herds, adopted a temporary program distributing praziquantel to control and eradicate the parasite E. granulosus in dogs (FARIAS et al., 2004). Unfortunately, this practice was discontinued.

The occurrence of hydatidosis $(10.3 \%)$ in cattle slaughtered under the regulation of the Federal Inspection Service in Rio Grande do Sul was presented by MAZZUTTI et al. (2011) were higher than that observed in this study. The prevalence of these lesions in the gaucho herd contrast to those observed in the other Brazilian states, where ovine breeding is not significant. VECHIATO et al. (2011) observed only a 
Table 1 - Average rates of hydatidosis, cysticercosis, and tuberculosis infection in cattle slaughtered between the years 2009 and 2017 in the state of Rio Grande do Sul, Brazil under State Inspection by the Inspection Division of Animal Products (DIPOA).

\begin{tabular}{|c|c|c|c|c|c|c|c|}
\hline \multirow[t]{2}{*}{ Year } & \multirow[t]{2}{*}{ Slaughtered animals } & \multicolumn{2}{|c|}{-----------Hydatidosis---------- } & \multicolumn{2}{|c|}{--_--_-_ysticercosis----_--- } & \multicolumn{2}{|c|}{-----------Tuberculosis----- } \\
\hline & & Total & $\%$ & Total & $\%$ & Total & $\%$ \\
\hline 2009 & 173,753 & 14,162 & 8.2 & 1,890 & 1.1 & 247 & 0.1 \\
\hline 2010 & 916,082 & 72,899 & 8.06 & 11,573 & 1.3 & 1,242 & 0.1 \\
\hline 2011 & 957,307 & 71,879 & 7.5 & 11,519 & 1.2 & 1,417 & 0.25 \\
\hline 2012 & 960,916 & 70,813 & 7.4 & 11,075 & 1.6 & 1,380 & 0.1 \\
\hline 2013 & 398,830 & 28,682 & 7.2 & 4,797 & 1.1 & 739 & 0.2 \\
\hline 2014 & $1,053,992$ & 87,292 & 8.3 & 11,023 & 1.1 & 2,020 & 0.2 \\
\hline 2015 & $1,002,473$ & 62,056 & 6.2 & 11,510 & 1.2 & 927 & 0.1 \\
\hline 2016 & $1,002,535$ & 55,487 & 5.4 & 15,548 & 1.5 & 1,209 & 0.1 \\
\hline 2017 & $1,025,656$ & 60,219 & 5.9 & 13,342 & 1.3 & 1,414 & 0.1 \\
\hline Total & $7,509,544$ & 523,399 & 7.0 & 92,277 & 1.2 & 10,595 & 0.1 \\
\hline
\end{tabular}

$0.6 \%$ hydatidosis infection rate in animals slaughtered in São Paulo originated from Mato Grosso do Sul, Paraná, Goiás, and Mato Grosso State.

Cysticercosis was diagnosed, on average, in $1.21 \%$ of slaughtered bovine carcasses, without significant variations, throughout the evaluated time period (Table 1). Infection frequency was less than $1 \%$ in 6 out of 19 regions, with the lowest mean levels in Santa Rosa and Soledade (0.5\%) (Figure 2). Conversely, the regions of Santa Maria, Osório, and São Luiz Gonzaga had infection rates close to $2 \%$. Although, there is no representative study of the Brazilian herd cysticercosis infection rates considering the values of municipal, state, and federal inspections in Brazil, ROSSI et al. (2014) reviewed several studies and observed that the disease is present in all regions of Brazil. Higher rates were observed in Southeastern and Southern regions. The higher prevalence in these regions can both be associated with epidemiological factors or considered a consequence of the greater number of studies available from these regions due to the importance of cattle breeding in these areas. A more comprehensive study evaluating 75,983,590 cattle slaughtered between the years 2007 and 2012, and inspected under the Federal Inspection Service, demonstrated that the national prevalence of the disease in cattle was $1.05 \%$ (DUTRA et al., 2012).

The data identifying cysticercosis lesions in slaughterhouses does not reflect the reality, which makes the findings more worrisome. According to the OIE (2014), meat inspection detects approximately $15-50 \%$ of infected carcasses. WALTER and KOSKE (1980) pointed out that low detection rates are likely the result of animals presenting only moderate infections, with discrete lesions and incision sites restricted, since notable cuts reduce commercial value.

The Food and Agriculture Organization of the United Nations (FAO) considers acceptable rates of bovine cysticercosis between 1 and $3 \%$ (FAO, 1986), indicating the adoption of monitoring and control measures. However, when prevalence exceeds these levels urgent sanitary actions are recommended to control the disease, as there is an imminent risk to public health (FAO, 1986). Infection control and prevention aims to interrupt the agent life cycle, and must be adopted immediately in the Santa Maria, Osório, São Luiz Gonzaga, and Uruguaiana regions. This initiative should be a coordinated and involve continuous interaction between the meat 
industries, producers, and official service, including inspection bodies and health surveillance. A detailed and individual evaluation of slaughtering worksheets could give a better estimation of municipalities and / or herds with higher prevalence rates. Thus, attempts to control this outbreak and must be directed to the properties with the highest level of infection.

The bovine is the intermediate host and ingests the $T$. saginata eggs excreted by the humans, which are the definitive host. Eggs can contaminate pastures and remain viable for several months. They can also be disseminated in water sources and rivers, allowing contamination of animals and humans (SANTOS \& BARROS, 2009). Therefore, the presence of bovine cysticercosis, diagnosed in abattoirs, reflects an important lack of hygiene resulting from inefficient sewage treatment and public health issues. The infection rates remain constant and localized in certain regions of the state, demonstrating the lack of concrete actions to reduce the occurrence of the disease.

The mean state index of tuberculosis diagnoses $(0.14 \%)$ was lower than that for hydatidosis (7.11\%) or cysticercosis $(1.21 \%)$ and lower than other states in the country (OLIVEIRA, 2008; BAUMGARTEN et al., 2016). The regions of Estrela (0.7\%), Santa Maria (0.23\%), Caxias do Sul (0.22\%), and Santa Rosa $(0.2 \%)$ presented the highest infection rates. In these regions there was also a higher reported frequency of in vivo diagnoses (TODESCHINI et al., 2018). The four regions where tuberculosis is most frequently diagnosed are small to medium-sized, consisting of dairy and/or mixed and intensively managed herds. Association of these characteristics with the management, climate, proximity between properties, and commercialization of animals contributes to the maintenance of disease in milk producing regions of the state (OLIVEIRA, 2008; TODESCHINI et al., 2018; BAUMGARTEN et al., 2016).

In contrast, the regions of Uruguaiana $(0.03 \%)$, Bagé $(0,05 \%)$, and Alegrete $(0,06 \%)$ are characterized by the production of beef cattle in an extensive grazing system where it is difficult for cattle to transmit the disease. Also, it is possible that the animals reacting to tuberculin tests are directed to abattoir under state inspection or that they represent herds or specific properties within these regions.

Inspection carried out in slaughterhouses plays a major role in maintaining public health, as it is responsible for the identification of lesions and/or alterations in carcasses and organs destined for consumption. Additionally, inspections act as a source of statistical data for health surveillance initiatives (BAVIA, 2012 ).

\section{CONCLUSION}

Hydatidosis, cysticercosis, and tuberculosis result in condemnation of cattle carcasses from the state of Rio Grande do Sul slaughtered in abattoirs monitored by state inspections. Condemnation rates vary according to the disease and region. This suggests the regionalization and maintenance of infectious cycles, resulting in direct industrial productivity losses and consequent risks to public health. Condemnation data from the official sanitary inspection system constitute an important tool for directing policies to control these diseases. Preventive measures, coordinated by government agencies and the meat industries, should be established. Additionally, producers should be subsidized when reducing the prevalence of diseases in their herds. The lack of integration between inspection records and sanitary surveillance in public health harms the initiatives to reduce the impact of these zoonoses on humans.

\section{ACKNOWLEDGMENTS}

The authors thank the State Inspection Service from Division of Inspection of Products of Animal Origin (DIPOA) and the Statistical Sector of the Secretariat of Agriculture, Livestock, and Irrigation (SEAPI) of Rio Grande do Sul State for the data transfer.

\section{DECLARATION OF CONFLICT OF INTEREST}

The authors declare no conflict of interest. The founding sponsors had no role in the design of the study; in the collection, analyses, or interpretation of data; in the writing of the manuscript, and in the decision to publish the results.

\section{REFERENCES}

BAUMGARTEN, K. D. et al. Prevalence and risk factors for bovine brucellosis in the State of Santa Catarina, Brazil. Semina. Ciências Agrárias, v. 37, p. 3425, 2016. Available from: <http://www.uel.br/ revistas/uel/index.php/semagrarias/article/view/27282>. Accessed: Jul. 03, 2018. doi: 10.5433/1679-0359.2016v37n5Supl2p3659.

BAVIA, M. E. et al. Spatial scan statistic in the detection of risk areas for bovine cysticercosis in the state of Bahia. Arquivo Brasileiro de Medicina Veterinária e Zootecnia, v.64, n.5, p.1200-1208, 2012. Available from: <http://www.scielo.br/scielo. php?script $=$ sci_arttext\&pid=S0102-09352012000500018\&lng=en $\& n r m=i s o \& t \operatorname{lng}=p t>$. Accessed: Jun. 01, 2016. doi: 10.1590/S010209352012000500018 .

BRASIL, 1952. Decreto $N^{0} 30.691$, de 29 de março de 1952. Aprova o Novo Regulamento da Inspeção Industrial e Sanitária de Produtos de Origem Animal. Brasília, DF, 1952. Available from: <http:// www.planalto.gov.br/ccivil_03/decreto/1950-1969/d30691.htm>. Accessed: Oct. 12, 2017.

BRASIL, 1989. Lei $\mathbf{n}^{\circ}$ 7.889, de 23 de novembro de 1989. Dispõe sobre a inspeção sanitária e industrial dos produtos de origem 
animal, e dá outras providências. Brasília, DF, 1989. Available from: <http://www.planalto.gov.br/ccivil_03/Leis/L7889.htm>. Accessed: Oct. 12, 2017

BRASIL, 2017. Decreto $\mathbf{N}^{\circ} \mathbf{9 . 0 1 3}$, de 29 de março de 2017. Regulamenta a Lei ${ }^{\circ} 1.283$, de 18 de dezembro de 1950, e a Lei n 7.889 , de 23 de novembro de 1989, que dispõem sobre a inspeção industrial e sanitária de produtos de origem animal. Brasília, DF, 2017. Available from: <http://www.planalto.gov.br/ccivil_03/_ato20152018/2017/decreto/d9013.htm>. Accessed: Oct. 12, 2017.

BRASIL. Ministério da Agricultura Pecuária Agronegócio, 2010. Available from: <http:/www.agricultura.gov.br/portal/page/portal/ Internet-MAPA/pagina-inicial/animal/produto-final/sisbi>. Accessed: Jun 01, 2016

DUTRA, L. H. et al. The prevalence and spatial epidemiology of cysticercosis in slaughtered cattle from Brazil. Semina: Ciências Agrárias, v. 33, n. 5, p. 1887-1896, 2012. Available from: <http:// dx.doi.org/10.5433/1679-0359.2012v33n5p1887>. Accessed: Jun. 01, 2016. doi: $10.5433 / 1679-0359.2012 v 33 n 5 p 1887$.

FAO. Animal health yearbook. Rome: FAO, 1986. 51 p.

FARIAS, L.N. et al. Echinococcosis in southern Brazil: efforts toward implementation of a control program in Santana do Livramento, Rio Grande do Sul. Revista do Instituto de Medicina Tropical. v. 46, n. 6 , p. 153,2004 . Available from: $<$ http://dx.doi.org/10.1590/S003646652004000300006>. Accessed: Jun. 01, 2016. doi: 10.1590/S003646652004000300006

FRUET, A. P. B. et al.Economic losses due to condemnation cattle viscera in slaughterhouse in Santa Maria, Rio Grande do Sul. Revista Brasileira de Ciência Veterinária. v. 20, n. 2, p. 99 - 103, 2013.Available from: <https://doi.org/10.22409/rbcv.v20i2.125> Accessed: Jun. 01, 2016. doi: 10.22409/rbcv.v20i2.125.

GERMANO, P. M. L.; GERMANO, M. I. S. Higiene e vigilância sanitária de alimentos. 3 ed. Barueri: Manole, 2008. 986p.

HERNÁNDEZ-RUSSO, Z; CABRERA-STÁBILE， P. Epidemiological aspects of cystic echinococcosis in the northwest region of Uruguay. Revista Ibero-Latinoamericana de Parasitología, v.69, n.2, p. 223-227, 2010. Available from: $<$ http://www.parasitaria.org/journal/download/pdf/id/70>. Accessed: Oct. 01, 2017.

IBGE, Instituto Brasileiro de Geografia e Estatística, Estatística da Produção Pecuária Brasil. Available from: $<$ https://sidra.ibge.gov. br>. Accessed:Oct. 02, 2017.

IRABEDRA, P.; SALVATELLA, R. The southern cone sub-regional project on cystic echinococosis control and surveillance. Revista Peruana de Medicina Experimental y Salud Publica, v. $27 \mathrm{n}$. 4 p. 598-603, 2010. Available from: <http://www.scielo.org.pe/ scielo.php?script $=$ sci_arttext\&pid=S1726-46342010000400017>. Accessed: Mar. 15, 2016.

MAZZUTTI, K.C. et al. Ocorrência de cisticercose, faciolose e hidatidose em bovinos abatidos sob inspeção Federal no Rio Grande do Sul, Brasil- 2005 a 2010. In: ANAIS DO $\mathbf{3 8}^{\circ}$ CONGRESSO BRASILEIRO DE MEDICINA VETERINÁRIA (CONBRAVET), 2011. Available from: $<$ http://www.sovergs.com.br/ site/38conbravet/resumos/427.pdf $>$. Accessed: Jun. 12, 2015.
MURAKAMI, P. S. et al. Bovine tuberculosis: animal and human health. Arquivos de Ciência Veterinária e Zoologia da Unipar, v.12, n.1, p. 67-74, 2009. Available from: <https://doi.org/10.25110/ arqvet.v12i1.2009.2936>. Accessed: Jun 01, 2016. doi: 10.25110/ arqvet.v12i1.2009.2936

O'REILLY, L. M.; DABORN, C. J. The epidemiology of Mycobacterium bovis infections in animals and man: a review. Tubercle and Lung Disease, v. 76, suppl. 1, p. 1-46, 1995.

OIE. World Organization for Animal Health. OIE Terrestria Manual Code, 2014. Available from: <http://www.oie.int/ international-standard-setting/terrestrial-code/access-online $>$. Accessed: May. 16, 2017.

OLIVEIRA, V. M. et al. Retrospective analysis of the factors associated to the distribution of bovine tuberculosis in the State of Rio de Janeiro. Arquivos Brasileiros de Medicina Veterinária e Zootecnia, v. 60, n.3, p. $574-579,2008$. Available from: $<$ http://www.scielo.br/scielo. php?script $=$ sci_arttext\&pid $=$ S0102-09352008000300008\&lng $=$ en \&nrm=iso\&tlng=pt $>$. Accessed: Jun. 01, 2016. doi: 10.1590/S010209352008000300008.

ROSSI, G. A. M et al. Bovine cysticercosis situation in Brazil. Semina - Ciências Agrárias. v. 35, n. 2, p. 927-938, 2014. Available from: <www.uel.br/revistas/uel/index.php/semagrarias/ article/viewFile/14259/14295>. Accessed: Jun. 12, 2016. doi: 10.5433/1679-0359.2014v35n2p927.

SANTOS, D.V. et al. Análise das principais lesões encontradas nos abatedouros registrados na CISPOA. Informativo Técnico, n. 4, 2010. Available from: <http://www.agricultura.rs.gov.br/upload/ arquivos/201611/25103958-see-artigo-17analise-das-principaislesoes-encontradas-nos-abatedouros-registrados-na-cispoa.pdf.>. Accessed: Oct. 02, 2017.

SANTOS, J. M. G.; BARROS, M. C. R. Cysticercus bovis e Cysticercus cellulosae: important endoparasites in the beef trade. Revista em Agronegócios e Meio Ambiente, v.2, n. 1, p. 21-39, 2009. Available from: <http://periodicos.unicesumar.edu.br/index.php/ rama/article/view/619/707>. Accessed: Jun. 01, 2016.

SHAKESPEARE, M. Zoonoses, 2 ed, North Yorkshire: TJ International, 2009.

TODESCHINI, B. et al. Ocorrência de brucelose e tuberculose bovinas no Rio Grande do Sul com base em dados secundários. Pesquisa Veterinária Brasileira, v. 38, n. 1, p. 15-22, 2018. Available from $<$ http://www.scielo.br/scielo.php?script $=$ sci_arttext\&pid=S0100 736X2018000100015\&lng=en\&nrm=iso>. Accessed: Jul. 03, 2018. doi: 10.1590/1678-5150-pvb-4712.

VECHIATO, T.A.F. et al. Retrospective study of liver abscesses in beef cattle slaughtered in a Brazilian abattoir. Brazilian Journal of Veterinary Research and Animal Science, v. 48, n. 5, p. 384-391, 2011. Available from: <http://www.revistas.usp.br/bjvras/article/ view/34404/37142>. Accessed: Jun. 01, 2016. doi: 10.11606/S141395962011000500005 .

WALTER, M.; KOSKE, J.K. Taenia saginata cysticercosis: A comparison of routine meat inspection and carcass dissection results in calves. Veterinary Research, v.106, p.401-402, 1980. Available from: <http://dx.doi.org/10.1136/vr.106.18-20.401>. Accessed: Jun. 01, 2016. doi: 10.1136/vr.106.18-20.401. 